\title{
Effect of Insecticides Sprayed on Leaves and Applied via Soil to Aphis illinoisensis Shimer, 1866 (Hemiptera: Aphididae) on Grapevines
}

\author{
Cléber Antonio Baronio ${ }^{1}$ Aline Nondillo ${ }^{2}$, Uemerson Silva da Cunha ${ }^{1}$, Marcos Botton²
}

(1) Departamento de Fitossanidade - Universidade Federal de Pelotas, Caixa Postal 354, CEP: 96010-900, Pelotas, Rio Grande do Sul, Brazil

(2) Laboratório de Entomologia, Embrapa Uva e Vinho, Caixa Postal 130, CEP: 95700-000, Bento Gonçalves, Rio Grande do Sul, Brazil

Submitted for publication: October 2015

Accepted for publication: December 2015

Key words: Grapevine aphid, chemical control, pest management, azadirachtin

\begin{abstract}
High infestations by the grapevine aphid Aphis illinoisensis (Hemiptera: Aphididae) have been observed in vineyards in southern Brazil, retarding plant growth and causing premature berry drop. This study evaluated the effect of insecticides on the control of the species in two experiments carried out in a greenhouse. The first control experiment for $A$. illinoisensis was conducted with seedlings of Vitis vinifera var. 'Cabernet Franc' to assess the effect of azadirachtin (Azamax ${ }^{\circledR}$ ) at dosages of 2.4 and $3.6 \mathrm{~mL}$ a.i. (active ingredient)/100 $\mathrm{L}$ of water, with reapplication seven days after the first application (DAFA). To compare its effect, the neonicotinoids imidacloprid (Provado $200 \mathrm{SC}^{\circledR}$ ) and thiamethoxam (Actara 250 $\mathrm{WG}^{\circledR}$ ) were sprayed at dosages of $8 \mathrm{~mL}$ or $\mathrm{g}$ a.i./100 $\mathrm{L}$ of water in foliar application without reapplication. The second experiment compared the effect on $A$. illinoisensis by spraying these neonicotinoids at dosages of $8 \mathrm{~mL}$ or $\mathrm{g}$ a.i./100 $\mathrm{L}$ in foliar applications and of $0.05 \mathrm{~mL}$ or $\mathrm{g}$ a.i./100 $\mathrm{L}$ applied in the soil. Evaluations were performed at $0,1,5,7,10$ and 14 DAFA. Imidacloprid and thiamethoxam effectively controlled $A$. illinoisensis in both forms of application [soil and foliar], while azadirachtin at the dosage of 3.6 ml a.i./100 L reapplied seven days after the first application provided $55.7 \%$ control. In conclusion, $A$. illinoisensis can be controlled effectively by employing neonicotinoids in the soil, while azadirachtin can be an alternative to reduce infestation pressure.
\end{abstract}

\section{INTRODUCTION}

Viticulture is an important economic and social activity in Brazil, both directly and indirectly, and also is important for the cultivation and processing industry and for tourism (Mello, 2014). In all wine-producing regions of the world, pests and diseases pose a major obstacle to the expansion of grapevine cultivation, affecting the quantity and the quality of the product (Kuhn \& Nickel, 1998). In recent years, the incidence of infestations by the grapevine aphid Aphis illinoisensis Shimer, 1866 (Hemiptera: Aphididae) in vineyards in southern Brazil has increased significantly. The species is originally from North America, but it also occurs in Central and South America and was introduced into Europe in 2005 (Tsitsipis et al., 2005).

The feeding insects retard plant growth and shoot formation, and cause leafroll in new leaves; when they reach high levels, the aphids can be found in clusters, causing the berries to drop (Baker, 1917). In Brazil, A. illinoisensis reached harmful levels for grapevine culture only recently
(Baronio et al., 2014), and this has made it necessary to apply insecticides for pest control, especially when the attack occurs when the plants are producing shoots and soon after flowering, or if the insect is damaging the clusters (Zaaqiq, 2007). However, no information is available about the effect of insecticides in controlling this pest in Brazil (Agrofit, 2014). Because of this lack of information, producers spray mainly pyrethroid and organophosphorus insecticides, which, because of their low selectivity for natural enemies, induce outbreaks of secondary pests, especially the broad mite, Polyphagotarsonemus latus (Banks, 1904) (Acari: Tarsonemidae) (Botton et al., 2004), the two-spotted spider mite, Tetranychus urticae Koch, 1836 (Acari: Tetranychidae) (Valadão et al., 2012), and the mealybug Pseudococcus longispinus (Targioni-Tozetti, 1867) vector of grapevine leafroll-associated virus (GLRaV-3) in Brazil (Kuniyuki et al., 2005).

One alternative to control aphids on grapevines is the neonicotinoids imidacloprid and thiamethoxam, which are 
already used for the management of the grape phylloxera Daktulosphaira vitifoliae (Fitch, 1856) (Hemiptera: Phylloxeridae) and Eurhizococcus brasiliensis Wille, 1922 (Hemiptera: Margarodidae) and are applied as a foliar spray as well as a soil drip or irrigation (Botton et al., 2004; 2013; Nondillo et al., 2014). The neonicotinoid insecticides imidacloprid and thiamethoxam are currently recommended for the control of $D$. vitifoliae in spray form at rates of 8 $\mathrm{mL}$ and $7.5 \mathrm{~g}$ a.i./100 L water (Botton et al., 2004), and for E. brasiliensis, applied to the soil at doses from 0.12 to $0.35 \mathrm{~g}$ a.i./plant (Botton et al., 2013), respectively. Based on the results it appears that this form of treatment is also effective for the control of A. illinoisensis, and in this case it was consider that application to the soil can be an alternative to preserve non-target organisms, particularly pollinators (Oliveira et al., 2013; Rossi et al., 2013).

Another alternative is azadirachtin, which is present in neem plants (Azadirachta indica A. Juss.) and recently was registered for the control of the red-banded thrips, Selenothrips rubrocinctus (Giard, 1901), in vineyards (UPLBrasil, 2015). Azadirachtin inhibits feeding, is a repellent and affects metamorphosis, preventing the normal development of insect pests in different crops (Schmutterer, 1990; Mordue \& Nisbet, 2000; Martinez \& Van Emden, 2001). Another advantage of azadirachtin-based insecticides is their low toxicity to humans (Isman, 2006). They therefore can be used in organic production systems and/or when the attack occurs in the pre-harvest period due to the absence of residues and the rapid degradation of the active ingredient (Mordue et al., 2010; Agrofit, 2014; IBD Certifications, 2014).

This study aimed to evaluate the effect of azadirachtin, imidacloprid and thiamethoxam sprayed on leaves and applied via soil for the control of A. illinoisensis in vineyards.

\section{MATERIALS AND METHODS}

The experiments were carried out in a greenhouse at Embrapa Uva e Vinho in Bento Gonçalves, State of Rio Grande do Sul, Brazil. A. illinoisensis adults were collected in commercial vineyards of fine table grapes (Vitis vinifera) 'Itália', grown in a trellis system $(1.8 \times 1.25 \mathrm{~m})$ under plastic cover in Caxias do Sul, State of Rio Grande do Sul $\left(29^{\circ} 08^{\prime} 01^{\prime \prime}\right.$; $\left.51^{\circ} 06^{\prime} 06^{\prime \prime} \mathrm{W}\right)$. The insects were transported to a greenhouse at the Entomology Laboratory of Embrapa Uva e Vinho, where they were inoculated on seedlings of $V$. vinifera $\mathrm{cv}$. 'Cabernet Sauvignon' cultivated in a greenhouse. The insects were kept isolated on plants inside the greenhouse between April and October 2013, in a rearing stock kept in cages isolated from the plants used in the experiments conducted in the greenhouse.

Two experiments were conducted, evaluating azadirachtin, applied in the form of a foliar spray, and imidacloprid and thiamethoxam, both sprayed and applied to the soil (Table 1). V. vinifera cv. 'Cabernet Franc' plants grown on the rootstock 'Paulsen 1103' were cultivated individually in polyethylene pots $(1.7 \mathrm{~L})$ containing a mixture of soil, organic substrate $\left(\right.$ Mecplant ${ }^{\mathbb{R}}$ ) and vermiculite in a ratio of $3: 1: 1$. One month after the onset of sprouting, each plant was placed in a cage with 10 females of $A$. illinoisensis aged seven to 14 days, which were kept in a cage made of acetate sheets containing eight holes (4 $\mathrm{cm}$ in diameter). The holes were covered with nonwoven fabric that was glued over them, while the upper part was closed with the same tissue, using rubber bands, to prevent the insects from escaping.

Ten days after the grapevine sprouts had been infested with A. illinoisensis adults using a camel-hair brush, a preliminary count was made of the number of live insects (nymphs and adults) present on the leaves and shoots with the aid of a pocket magnifying glass (10 x magnification)

TABLE 1

Commercial product, active ingredient, dose, chemical group and toxicity class of insecticides used in the experiments to control Aphis illinoisensis on grapevines in a greenhouse.

\begin{tabular}{|c|c|c|c|c|c|}
\hline \multirow{2}{*}{$\begin{array}{l}\text { Commercial } \\
\text { product }\end{array}$} & \multirow{2}{*}{ Active ingredient } & \multicolumn{2}{|c|}{ Dose } & \multirow{2}{*}{ Chemical group } & \multirow{2}{*}{$\begin{array}{l}\text { Toxicity } \\
\text { class }\end{array}$} \\
\hline & & a.i. & c.p. & & \\
\hline \multicolumn{6}{|c|}{ Experiment 1} \\
\hline Azamax $^{\circledR *}$ & Azadirachtin & 2.4 & 200 & Tetranotriterpenoid & III \\
\hline $\operatorname{Azamax}^{\circledR *}$ & Azadirachtin & 3.6 & 300 & Tetranotriterpenoid & III \\
\hline Provado $200 \mathrm{SC}^{\circledR}$ & Imidacloprid & 8 & 40 & Neonicotinoid & III \\
\hline Actara $250 \mathrm{WG}^{\circledR}$ & Thiamethoxam & 8 & 32 & Neonicotinoid & III \\
\hline Control & - & - & - & - & - \\
\hline \multicolumn{6}{|c|}{ Experiment 2} \\
\hline \multicolumn{6}{|c|}{ Foliar application $^{1}$} \\
\hline Provado $200 \mathrm{SC}^{\circledR}$ & Imidacloprid & 8 & 40 & Neonicotinoid & III \\
\hline Actara $250 \mathrm{WG}^{\circledR}$ & Thiamethoxam & 8 & 32 & Neonicotinoid & III \\
\hline \multicolumn{6}{|c|}{ Soil application $^{2}$} \\
\hline Provado $200 \mathrm{SC}^{\circledR}$ & Imidacloprid & 0.05 & 0.25 & Neonicotinoid & III \\
\hline Actara $250 \mathrm{WG}^{\circledR}$ & Thiamethoxam & 0.05 & 0.20 & Neonicotinoid & III \\
\hline Control & - & - & - & - & - \\
\hline
\end{tabular}

${ }^{1}$ grams or $\mathrm{mL}$ of active ingredient (a.i.) or commercial product (c.p.) per 100 litres of water, sprayed to runoff point;

${ }^{2}$ grams or $\mathrm{mL}$ of a.i. or c.p. per plant; * reapplication of insecticide seven days after the first application. 
before the treatments were applied. In the first experiment, the insecticides (Table 1) were sprayed until the runoff point, using a Jacto PJH manual backpack sprayer with $20 \mathrm{~L}$ capacity, a working pressure of $6 \mathrm{kgf} / \mathrm{cm}^{2}$ and a Teejet TXA $800015 \mathrm{VK}$ spray tip. In the control treatment, only water was sprayed. The treatments with azadirachtin were reapplied seven days after the first application (DAFA).

In the second experiment the foliar spray of neonicotinoid insecticides was the same as in the first experiment, and the aim was to compare the effect of the spraying with the effect of the application of the same active ingredients (a.i.) in the soil, at a dose of $0.05 \mathrm{~g}$ per plant, diluted in $50 \mathrm{~mL}$ of water and showered on the surface of the base of the plants with a graduated beaker. Each treatment was repeated 10 times, in a fully randomised design, considering each plant as one replicate.

The effect of the treatments on A. illinoisensis was evaluated by recording the number of live insects (nymphs and adults) per plant at 1, 5, 7, 10 and 14 DAFA. The evaluation was performed with the aid of a pocket magnifying glass $(10 \mathrm{x})$, considering dead aphids as those that showed no perceptible movement and an opaque and dehydrated body.

The efficacy provided by the insecticide for A. illinoisensis control was calculated using the Abbott equation (Abbott, 1925). The mean number of surviving insects was compared among the treatments by Tukey's test $(\mathrm{p}<0.05)$, using Statistica 7.0 software (Statsoft, 2004).

\section{RESULTS}

In both experiments, the mean number of adults and nymphs of $A$. illinoisensis per plant before the application of the insecticides ranged from 136 to 148 in the first experiment (Table 2), and 236 to 254 insects per plant in the second experiment (Table 3). There was no significant difference $(p<0.05)$ among the treatments, demonstrating the uniformity of the artificial infestation.

In the first experiment, in the evaluation conducted at 1 DAFA, azadirachtin $(2.4 \mathrm{~mL}$ a.i./100 L) reduced the aphid population by 29.2 , differing significantly from the control (Table 2). The results of this experiment show that, one day after the application, azadirachtin caused lower mortality, even in the treatment with a $50 \%$ higher dosage.

In the evaluation conducted at 5 DAFA, the plants treated with azadirachtin were more heavily infested than in the first evaluation (Table 2). However, compared to the control treatment the infestation was reduced by 44.4 and $29.5 \%$ at doses of 2.4 and $3.6 \mathrm{~mL}$ a.i./100 L of azadirachtin respectively (Table 2).

At 7 DAFA, azadirachtin decreased the infestation of A. illinoisensis by 15.4 and $26.1 \%$ (2.4 and $3.6 \mathrm{~mL}$ a.i./100 L) respectively, with a significant effect compared to the control only at the higher dose (Table 2). Thus, even when increasing the dose of azadirachtin there was no significant reduction in the $A$. illinoisensis population at 7 DAFA. At 10 DAFA, or three days after the second application (DASA) of azadirachtin, the insect population was lower in the treatments with azadirachtin compared with the assessment at 7 DAFA, with reductions in infestation by 46.6 and $46.9 \%$ in the treatments with 2.4 and $3.6 \mathrm{~mL}$ a.i./100 $\mathrm{L}$ of water respectively, differing from the control treatment.

In the final evaluation of the first experiment, performed at 14 DAFA, azadirachtin showed reductions in infestation of 46.1 and $55.7 \%(2.4$ and $3.6 \mathrm{~mL}$ a.i./100 L water respectively), differing from the control treatment (Table 2).

TABLE 2

Mean number $( \pm \mathrm{SE})$ of live insects per plant and corrected mortality percentage $(\% \mathrm{M})$ of Aphis illinoisensis in different periods after insecticide application to Vitis vinifera var. 'Cabernet Franc' plants in a greenhouse.

\begin{tabular}{|c|c|c|c|c|c|c|}
\hline \multirow[b]{3}{*}{ Treatment } & \multirow{3}{*}{$\begin{array}{l}\text { Dose }^{3} \\
\text { a.i. }\end{array}$} & \multirow{3}{*}{$\begin{array}{l}\mathbf{P C}^{4} \\
\mathrm{~N}^{5}\end{array}$} & \multicolumn{4}{|c|}{ Days after the first application (DAFA) } \\
\hline & & & \multicolumn{2}{|c|}{1} & \multicolumn{2}{|c|}{5} \\
\hline & & & $\mathrm{N}$ & $\% \mathrm{M}^{6}$ & $\mathrm{~N}$ & $\% \mathrm{M}$ \\
\hline Azamax $^{\circledR 2}$ (Azadirachtin) & 2.4 & $146 \pm 22 \mathrm{a}^{1}$ & $107 \pm 9.4 b$ & 29.2 & $164 \pm 14 b$ & 44.4 \\
\hline $\operatorname{Azamax}^{\circledR 2}$ (Azadirachtin) & 3.6 & $141 \pm 20 \mathrm{a}$ & $120 \pm 9.9 \mathrm{ab}$ & 20.7 & $207 \pm 24 b$ & 29.5 \\
\hline Provado $200 \mathrm{SC}^{\circledR}$ (Imidacloprid) & 8 & $142 \pm 19 \mathrm{a}$ & $10,8 \pm 3.1 \mathrm{c}$ & 92.9 & $0.0 \pm 0.0 \mathrm{c}$ & 100 \\
\hline Actara $250 \mathrm{WG}^{\circledR}$ (Thiamethoxam) & 8 & $136 \pm 17 \mathrm{a}$ & $102.9 \pm 7.9 b$ & 32.1 & $2.7 \pm 0.7 \mathrm{c}$ & 99.1 \\
\hline Control & & $148 \pm 20 \mathrm{a}$ & $151.6 \pm 15 \mathrm{a}$ & - & $294 \pm 29 a$ & - \\
\hline
\end{tabular}

Days after the first application (DAFA)

\begin{tabular}{|c|c|c|c|c|c|c|}
\hline \multirow[b]{3}{*}{ Treatment } & \multirow{2}{*}{\multicolumn{2}{|c|}{7}} & \multirow{2}{*}{\multicolumn{2}{|c|}{10}} & \multirow{2}{*}{\multicolumn{2}{|c|}{14}} \\
\hline & & & & & & \\
\hline & $\mathrm{N}$ & $\% \mathrm{M}$ & $\mathrm{N}$ & $\% \mathrm{M}$ & $\mathrm{N}$ & $\% \mathrm{M}$ \\
\hline Azamax $^{\circledR 2}$ (Azadirachtin) & $272 \pm 19 \mathrm{ab}$ & 15.4 & $174 \pm 21 b$ & 46.6 & $212 \pm 25 b$ & 46.1 \\
\hline $\operatorname{Azamax}^{\circledR 2}$ (Azadirachtin) & $238 \pm 16 b$ & 26.1 & $173 \pm 17 b$ & 46.9 & $174 \pm 11 b$ & 55.7 \\
\hline Provado 200 SC $^{\circledR}$ (Imidacloprid) & $0.0 \pm 0.0 \mathrm{c}$ & 100 & $0.0 \pm 0.0 \mathrm{c}$ & 100 & $0.0 \pm 0.0 \mathrm{c}$ & 100 \\
\hline Actara $250 \mathrm{WG}^{\circledR}$ (Thiamethoxam) & $0.7 \pm 0.7 \mathrm{c}$ & 99.8 & $0.0 \pm 0.0 \mathrm{c}$ & 100 & $0.0 \pm 0.0 \mathrm{c}$ & 100 \\
\hline Control & $322 \pm 29 a$ & - & $326.3 \pm 24 a$ & - & $392.9 \pm 26 a$ & - \\
\hline
\end{tabular}

${ }^{1}$ Means followed by lowercase letters in the same column do not differ by Tukey's test at $5 \%$ probability; ${ }^{2}$ Azadirachtin was reapplied seven days after the first application; ${ }^{3}$ Dose (g or mL a.i./100 L water) in leaf application; ${ }^{4} \mathrm{PC}$ : Pre-treatment count; ${ }^{5} \mathrm{~N}$ : Mean number of A. illinoisensis per plant; ${ }^{6}$ Corrected mortality $(\% \mathrm{M})($ Abbott, 1925). 
TABLE 3

Mean number $( \pm \mathrm{SE})$ of live insects per plant and corrected mortality percentage $(\% \mathrm{M})$ of Aphis illinoisensis in different periods after insecticide applications to the leaves and soil of Vitis vinifera var. 'Cabernet Franc' plants in a greenhouse.

\begin{tabular}{|c|c|c|c|c|c|c|}
\hline \multirow[b]{3}{*}{ Treatment } & \multirow{3}{*}{$\begin{array}{l}\text { Dose }^{2} \\
\text { a.i. }\end{array}$} & \multirow{3}{*}{$\begin{array}{l}\mathrm{PC}^{3} \\
\mathrm{~N}^{4}\end{array}$} & \multicolumn{4}{|c|}{ Days after the first application (DAFA) } \\
\hline & & & \multicolumn{2}{|c|}{1} & \multicolumn{2}{|c|}{5} \\
\hline & & & $\mathrm{N}$ & $\% \mathrm{M}^{5}$ & $\mathrm{~N}$ & $\% \mathrm{M}$ \\
\hline & & & \multicolumn{3}{|c|}{ Foliar application } & \\
\hline Provado $200 \mathrm{SC}^{\circledR}$ (Imidacloprid) & 8 & $245.8 \pm 26 \mathrm{a}^{1}$ & $38.1 \pm 7 \mathrm{c}$ & 88.1 & $0.3 \pm 0.1 b$ & 99.9 \\
\hline \multirow[t]{2}{*}{ Actara $250 \mathrm{WG}^{\circledR}$ (Thiamethoxam) } & 8 & $243.5 \pm 19 a$ & $219 \pm 19 b$ & 31.6 & $5.9 \pm 1.4 \mathrm{~b}$ & 98.5 \\
\hline & & & \multicolumn{2}{|c|}{ Soil application } & & \\
\hline Provado 200 SC $^{\circledR}$ (Imidacloprid) & 0.05 & $236.2 \pm 24 a$ & $231.5 \pm 22 b$ & 27.7 & $36.5 \pm 15 b$ & 90.6 \\
\hline Actara $250 \mathrm{WG}^{\circledR}$ (Thiamethoxam) & 0.05 & $242 \pm 21 \mathrm{a}$ & $215 \pm 26 b$ & 32.8 & $5.9 \pm 1.4 b$ & 98.5 \\
\hline Control & & $241.9 \pm 17 \mathrm{a}$ & $320.2 \pm 24 a$ & - & $386.5 \pm 29 a$ & - \\
\hline
\end{tabular}

Days after the first application (DAFA)

\begin{tabular}{|c|c|c|c|c|c|c|}
\hline \multirow[b]{3}{*}{ Treatment } & \multirow{2}{*}{\multicolumn{2}{|c|}{7}} & \multirow{2}{*}{\multicolumn{2}{|c|}{10}} & \multirow{2}{*}{\multicolumn{2}{|c|}{14}} \\
\hline & & & & & & \\
\hline & $\mathrm{N}$ & $\% \mathrm{M}$ & $\mathrm{N}$ & $\% \mathrm{M}$ & $\mathrm{N}$ & $\% \mathrm{M}$ \\
\hline & \multicolumn{6}{|c|}{ Foliar application } \\
\hline Provado 200 SC $^{\circledR}$ (Imidacloprid) & $0.0 \pm 0.0 \mathrm{~b}$ & 100 & $00 \pm 00 \mathrm{~b}$ & 100 & $00 \pm 00 b$ & 100 \\
\hline \multirow[t]{2}{*}{ Actara $250 \mathrm{WG}^{\circledR}$ (Thiamethoxam) } & $0.5 \pm 0.4 \mathrm{~b}$ & 99.9 & $00 \pm 00 \mathrm{~b}$ & 100 & $00 \pm 00 b$ & 100 \\
\hline & \multicolumn{6}{|c|}{ Soil application } \\
\hline Provado $200 \mathrm{SC}^{\circledR}$ (Imidacloprid) & $3.8 \pm 2.9 b$ & 99.0 & $00 \pm 00 b$ & 100 & $00 \pm 00 \mathrm{~b}$ & 100 \\
\hline Actara $250 \mathrm{WG}^{\circledR}$ (Thiamethoxam) & $0.0 \pm 0.0 \mathrm{~b}$ & 100 & $00 \pm 00 b$ & 100 & $00 \pm 00 b$ & 100 \\
\hline Control & $372.5 \pm 31 \mathrm{a}$ & - & $348.5 \pm 26 a$ & - & $390.1 \pm 42 \mathrm{a}$ & - \\
\hline
\end{tabular}

${ }^{1}$ Means followed by lowercase in the same column do not differ by Tukey's test at $5 \%$ probability; ${ }^{2}$ Dose (g or $\mathrm{mL}$ a.i./100 L water) in leaf application or (g or mL a.i./plant) via soil; ${ }^{3} \mathrm{PC}$ : Pre-treatment count; ${ }^{4} \mathrm{~N}$ : Mean number of $A$. illinoisensis per plant; ${ }^{5}$ Corrected mortality (\%M) (Abbott, 1925).

However, although the aphid population was reduced, the level of infestation in plants with two applications of azadirachtin, even with the $50 \%$ increase in concentration, remained fairly high, averaging 174 to 212 insects per plant, whereas in the control treatment the infestation level was more than 390 insects per plant (Table 2).

In the case of the neonicotinoids, in the evaluation conducted at 1 DAFA, imidacloprid in foliar application decreased the infestation of $A$. illinoisensis by $92.2 \%$, differing significantly from both thiamethoxam (32.1\%) and the control (Table 2). In the subsequent evaluations, at 5, 7, 10 and 14 DAFA, the neonicotinoids in the foliar application provided infestation reductions of more than $99 \%$, with $100 \%$ control at 10 and 14 DAFA. The levels of reduction were equivalent, thus confirming the efficacy of these insecticides for pest control.

In view of the observed efficacy of the neonicotinoids against $A$. illinoisensis in foliar application, the effect of these insecticides in the soil was also evaluated and compared to the powdered form (Table 3 ).

The evaluation conducted at 1 DAFA showed that imidacloprid and thiametoxam applied to the soil reduced the infestation by 32.8 and $27.7 \%$ respectively, which was equivalent to the foliar application of thiametoxam (31.6\%). Imidacloprid in foliar application showed a better effect than the other treatments, reducing infestation by $88.1 \%$ in the same period (Table 3 ).
Five days after the application of the neonicotinoids, thiamethoxam provided a $98 \%$ reduction of the infestation in both foliar and soil applications. This did not differ from imidacloprid, which provided population reductions of 90.6 and $99.9 \%$ in the soil and on leaves respectively (Table 3 ). At the subsequent evaluations (7, 10 and 14 DAFA), the insecticides provided excellent control of this insect population, regardless of the form of application, with 100\% control at 10 and 14 DAFA (Table 3).

\section{DISCUSSION}

The reduction in infestation observed after the application of azadirachtin was also observed by Bernardi et al. (2012), who evaluated the effect of insecticides on the control of the strawberry aphid, Chaetosiphon fragaefolli (Cockerell, 1901) (Hemiptera: Aphididae). Costa et al. (2010) found that azadirachtin (as Neemazal ${ }^{\circledR} ; 10 \mathrm{~mL}$ a.i. $/ 100 \mathrm{~L}$ water) afforded 91\% control of Aphis craccivora Koch, 1854 (Hemiptera: Aphididae) two days after application to seedlings of the cowpea Vigna ungiculata (L., 1753). However, it should be noted that the amount used for the control of $A$. craccivora was approximately five times higher than that used in this study.

Bernardi et al. (2012) observed a $28 \%$ reduction in the fecundity of females, regardless of the dosage used, compared to the control treatment, 15 days after the first application on C. fragaefoli. Whereas the azadirachtin dosages evaluated 
by these authors were similar to the dosages used in this study, the smaller effect on A. illinoisensis could be due to the lower susceptibility of the species, as the test of Bernardi et al. (2012) used direct contact of the insecticide on the aphids, and the effect of direct contact of this compound on aphids has been demonstrated in A. craccivora in beans (Stark \& Rangus, 1994). This reinforces the observation that the efficiency of azadirachtin depends on the target species.

In a study evaluating the effect of aqueous extracts of azadirachtin powder from seeds (neem) at concentrations of 0.4 and $1.4 \mathrm{~g}$ a.i./100 L water on Aphis gossypii Glover, 1877 (Hemiptera: Aphididae), Santos et al. (2004) found that females fed since birth with cotton-leaf discs treated at a dose of $1.4 \mathrm{~g}$ a.i./100 L did not generate progeny, while the control increased the production of nymphs 35-fold.

In this study, azadirachtin affected the colour and the mobility of the aphids, leaving the nymphs dark and nearly immobile. In addition to the observed effects, azadirachtin can cause physiological changes that affect growth, metamorphosis and reproduction, including feeding inhibition (Mordue \& Nisbet, 2000).

Bernardi et al. (2012), while evaluating the effect of insecticides on $C$. fragaefoli control in strawberry, observed an $83 \%$ reduction in aphid infestation with the application of thiamethoxam, with more superior efficiency than on A. illinoisensis in the same evaluation period. Thus, imidacloprid applied to the leaves showed the greatest shock effect on the grapevine aphid, even compared with the same dose of the active ingredient of thiamethoxam.

Studies on the control of $A$. illinoisensis were performed by Zaaqiq (2007), who evaluated organophosphorus insecticides (diazinon and chlorpyriphos) and the pyrethroid cypermethrin to control this species and demonstrated that all insecticides were effective in pest control. However, 60 days after the last application, the plants treated with cypermethrin showed high levels of insect infestation higher than in the plants treated with chlorpyriphos and diazinon. This effect, according to the author, was due to the negative impact of cypermethrin on natural enemies, thus increasing A. illinoisensis infestation. In this case, although the organophosphorus insecticides were effective in controlling the pest, they are not authorised for use in viniculture in Brazil (Agrofit, 2015).

The application of neonicotinoid insecticides are effective for $A$. illinoisensis control in vine seedlings, both in foliar and soil application. The pollinators that are present in flowering weeds in the vineyards may be affected negatively occur with foliar application, thus restricting this method of treatment. Grapevines are self-pollinated, resulting in a reduced presence of bees in the crop, while there is no significant effect of cropping system (conventional or organic) on the richness and abundance of pollinators (Brittain et al., 2010a). Even so, due to the fact that the foliar application of neonicotinoids can have a negative effect on the richness of some pollinators in vineyards (Brittain et al., 2010b), we suggest the soil application of these chemicals for pest control.

\section{CONCLUSIONS}

The insecticides thiamethoxam (Actara $250 \mathrm{WG}^{\circledR}, 8 \mathrm{~g}$ a.i./100 L of water by foliar spray or $0.05 \mathrm{~g}$ a.i./plant in the soil) and imidacloprid (Provado $200 \mathrm{SC}(8 \mathrm{~mL}$ a.i./100 L water or $0.05 \mathrm{~mL}$ a.i./plant in soil application) are effective in the control of Aphis illinoisensis in vineyards.

The insecticide azadirachtin (Azamax, 2.4 and $3.6 \mathrm{~mL}$ a.i./100L water), with reapplication seven days after the first application, is not effective in the control of Aphis illinoisensis in vineyards.

\section{LITERATURE CITED}

Abbott, W.S., 1925. A method of computing the effectiveness of an insecticide, J. Econ. Entomol. 18, 265-267.

Agrofit, 2015. Sistemas de agrotóxicos fitossanitários. Ministério da Agricultura, Pecuária e Abastecimento. http://extranet.agricultura.gov.br/ agrofit_cons/principal_agrofit_cons. Accessed: 21 January 2015.

Baker, A.C., 1917. Life history of Macrosiphum illinoisensis, the grapevine aphis. J. Agr. Res. 11, 85-89.

Baronio, C.A., Andzeiewski, S., Da Cunha, U.S. \& Botton, M., 2014. Biologia e tabela de vida de fertilidade do pulgão-preto em cultivares de videira. Pesqui. Agropecu. Bras. 49, 665-672.

Bernardi, D., Garcia, M.S., Botton, M. \& Da Cunha, U.S., 2012. Efeito da azadiractina sobre Chaetosiphon fragaefolli (Cockerell, 1901) (Hemiptera: Aphididae) na cultura do morangueiro. Rev. Bras. Frutic. 34, 93-101.

Botton, M., Rigenberg, R. \& Zanardi, O.Z., 2004. Controle químico da forma galícola da filoxera Daktulosphaira vitifoliae (Fitch, 1856) (Hemiptera: Phylloxeridae) na cultura da videira. Cienc. Rural 34, 1327-1331.

Botton, M., Bernardi, D., Efrom, C.F.S. \& Baronio, C.A., 2013. Eficiência de inseticidas no controle de Eurhizococcus brasiliensis (Hemiptera: Margarodidae) na cultura da videira. Bioassay 8, 01-05.

Brittain, C.A., Bommarco, R., Vighi, M., Settele, J. \& Potts, S.G., 2010a. Organic farming in isolated landscapes does not benefit flower-visiting insects and pollination. Biol. Consev. 143, 1860-1867.

Brittain, C.A., Vighi, M., Bommarco, R., Settele, J. \& Potts, S.G., 2010b. Impact of a pesticide on pollinator species richness at different spatial scales. Basic Appl. Ecol. 11, 106-115.

Costa, J.V.T.A., Bleicher, E., Cysne, A.Q. \& Gomes, F.H.T., 2010. Óleo e extrato aquoso de sementes de nim, azadiractina e acefato no controle do pulgão-preto do feijão-de-corda. Pesqui. Agropecu. Trop. 40, 238-241.

IBD Certifications, 2014. Relação de clientes certificados e aprovados. http://ibd.com.br/pt/ClienteResultadoPesquisaImpressao.aspx? INSUMO $=1 \&$ CLIENTE $=$ I0036\%20SP

Isman, M.B., 2006. Botanical insecticides deterrents and repellents in modern agriculture and an increasingly regulated world. Annu. Rev. Entomol. 51, 45-66.

Kuhn, G.B. \& Nickel, O., 1998. Viroses e sua importância na viticultura brasileira. Informe Agropecu. 19, 85-91.

Kuniyuki, H., Rezende, J.A.M., Wilink, M.C.G., Novo, J.P.S. \& Yuki, V.A., 2005. Transmissão do Grapevine leafroll-associated vírus 3 pela cochonilha Pseudococcus longispinus Targioni-Tozetti (Hemiptera: Pseudococcidae). Summa Phythopathol. 31, 65-68.

Martinez, S.S. \& Van Emden, H.F., 2001. Growth disruption, abnormalities and mortality of Spodoptera littoralis (Boisduval) (Lepidoptera: Noctuidae) caused by azadirachtin. Neotrop. Entomol. 30, 113-124. 
Mello, L.M.R., 2012. Vitivinicultura Brasileira: Panorama. Available in: $<$ http://www.uvibra.com.br/pdf/Panorama\%202012\%20\%20Vitivinicultura\%20Brasileira.pdf>. Accessed 20 March 2014.

Mordue, A.J. \& Nisbet, A.J., 2000. Azadirachtin from the neem tree Azadirachta indica: Its action against insects. An. Soc. Entomol. Bras. 29, 615-632.

Mordue, A.J., Morgan, E.D. \& Nisbet, A.J., 2010. Azadirachtin, a natural product in insect control. In: Lawrence, I.G. \& Sarjeet, S.G. (eds.). Insect control: Biological and synthetic agents. Academic Press, London. pp. 185 -197 .

Nondillo, A., Chaves, C.C., Fialho, F.B., Bueno, O.C. \& Botton, M., 2014. Evaluation of insecticides for the control of Linepithema micans (Hymenoptera: Formicidae). J. Econ. Entomol. 107, 215-222.

Oliveira, R.A., Roat, T.C., Carvalho, S.M. \& Malaspina, O., 2013. Sideeffects of thiamethoxam on the brain and midgut of the Africanized honeybee Apis mellifera (Hymenoptera: Apidae). Environ. Toxicol. 29, $1-12$.

Rossi, C.A., Roat, T.C., Ravares, D.A., Socolowski, P.C. \& Malaspina, O., 2013. Effects of sublethal doses of imidacloprid in Malpighian tubules of Africanized Apis mellifera (Hymenoptera, Apidae). Microsc. Res. Tech. 76, $552-558$.
Santos, T.M., Costa, N.P., Torres, A.L. \& Boiça-Junior, A.L. 2004. Effect of neem extract on the cotton aphid. Pesqui. Agropecu. Bras. 39, 1071-1076.

Schmutterer, H. 1990. Properties and potential of natural pesticides from neem tree. Annu. Rev. Entomol. 121, 121-128.

Stark, J.D. \& Rangus, T.M., 1994. Lethal and sublethal effects of neem insecticide formulation 'Margosan-O', on the pea aphid. Pest Manag. Sci. $41,155-160$

Statsoft, 2004. Statistica data analysis software system, v 7.0.

Tsitsipis, J.A., Angelakis, E., Margaritopoulos, J.T., Tsamandani, K. \& Zarpas, K.D., 2005. First record of the grapevine aphid Aphis illinoisensis in the island of Kriti, Greece. EPPO Bull. 35, 541-542.

UPL-Brasil, 2015. Azamax. http://www.uplbrasil.com.br/download. php?id=781

Valadão, G.S., Vieira, M.R., Pigari, S.A.A., Tabet, V.G. \& Silva, A.C., 2012., Resistência de cultivares de videira ao ácaro-rajado Tetranychus urticae na região de Jales, estado de São Paulo. Rev. Bras. Frutic. 34, 1051-1058.

Zaaqiq, I.H.M. 2007. Field studies on biology, ecology and management of grapevine aphid, Aphis illinoisensis (Shimer) (Homoptera: Aphididae) on some grapevine cultivars Vitis vinifera L. in Al-Arroub Agricultural Experimental Station, Palestine. Thesis, Hebron University, Hebron, Palestinian Territory. 